ӘОЖ 334.02

DOI: 10.46666/2021-2.2708-9991.10

https://www.jpra-kazniiapk.kz

\author{
АУЫЛ ШАРУАШЫЛЫҒЫ КӘСІПОРЫНДАРЫНДАҒЫ ҚАРЖЫ-ШАРУАШЫЛЫҚ \\ ҚЫЗМЕТ: ТЕОРИЯЛЫҚ АСПЕКТІЛЕР
}

\title{
FINANCIAL AND ECONOMIC ACTIVITY IN AGRICULTURAL ENTERPRISES: THEORETICAL ASPECTS
}

\section{ФИНАНСОВО-ХОЗЯЙСТВЕННАЯ ДЕЯТЕЛЬНОСТЬ В СЕЛЬСКОХОЗЯЙСТВЕННЫХ ПРЕДПРИЯТИЯХ: ТЕОРЕТИЧЕСКИЕ АСПЕКТЫ}

\author{
С.Б. АЛЬДЕШОВА* \\ экономика ғылымдарының магистрі \\ Г.T. AXMETOBA \\ Э.F.K. \\ М.С. ДАРИСКАЛИЕВА \\ экономика ғылымдарының магистрі \\ Х.Досмұхамедов атындағы Атырау университеті, Атырау, Қазақстан \\ *автордың электрондық поштасы: s.aldeshova@asu.edu.kz \\ S. ALDESHOVA* \\ Master of Economic Sciences \\ G. AKHMETOVA \\ C.E SC. \\ M. DARISKALIYEVA \\ Master of Economic Sciences \\ Kh. Dosmukhamedov Atyrau University, Atyrau, Kazakhstan \\ *corresponding author e-mail: s.aldeshova@asu.edu \\ С.Б. АЛЬДЕШОВА* \\ магистр экономических наук \\ Г.T. AXMETOBA \\ К.э.H. \\ М.С. ДАРИСКАЛИЕВА \\ магистр экономических наук \\ Атырауский университет им. Х. Досмухамедов, Атырау, Казахстан \\ *электронная почта автора: s.aldeshova@asu.edu.kz
}

Аңдатпа. Мақсаты - ауыл шаруашылығы кәсіпорындарында экономиканың басқа салаларынан ерекшеленетін Қаржы-шаруашылық қызметті жүргізу ерекшелігін көрсету, ол көбінесе ассортиментпен, өндірілетін өнім көлемімен және құндық мәнде өткізумен сипатталады, ол өндірістік қуаттардың сапасына, тозуына, қажетті шикізаттың, материалдардың болуына, өнімді өткізу нұсқаларына тікелей тәуелді болады. Мынадай міндетmер шешімін табады: аграрлық саланы қалыптастырудағы есепке алу проблемалары зерделенген; осы саладағы шаруашылықтарда экономикалық белсенділікті күшейтуде қиындықтар анықталған; кең ауқымды, жедел келіп түсетін ақпарат болған кезде жерді, өндірістік қорларды, материалдық, қаржылық және еңбек ресурстарын пайдалану тиімділігін арттыруға, шығындарды азайтуға, агроөнеркәсіптік кешен өнімдерінің рентабельділігін арттыруға және шаруашылықтардың қаржы-экономикалық жағдайын жақсартуға ықпал ететін шаралар жүйесі ұсынылған. Жүргізілген талдау нәтижелері сыртқы фракторлармен (инфляция, салааралық алмасудың тепе-теңдігінің бұзылуы, төлемге қабілетті сұраныс, тұтынушылардың табыс деңгейі және шаруашылық жүргізудің басқа да экономикалық жағдайлары) қатар қаржы-шаруашылық қызметке ішкі факторлар да үлкен әсер ететінін көрсетеді: активтердің құрылымын оңтайландыру, инвестициялықинновациялық процес-терді енгізу, аграрлық секторды техникалық және технологиялық жаңғырту. Ауыл шаруашылығындағы бухгалтерлік есеп өндірістік процестердің барысы, рентабельділіктің өсуі және жұмыс сапасының жақсаруы туралы қажетті ақпарат беруге 

ықпал етеді. Негізгі қорытындылар - аграрлық бейіндегі кәсіпорындарда есепке алуды ұйымдастыру кезінде озық ақпараттық технологияларды қолдануды, пайдаланушылардың әртүрлі топтарының қажеттіліктеріне бейімделу бойынша жаңа мүмкіндіктерді іске асыруды, басқа бағдар-ламалармен өзара іс-қимыл тетіктерін дамытуды көздеу қажет. Тиімді агроөнеркәсіптік өнді-ріс шаруашылық жүргізуші субъектінің тұрақты қаржылық жағдайында ғана мүмкін болады.

Abstract. The goal is to show the specifics of conducting financial and economic activities in agricultural enterprises, which differs from other sectors of economy, which is more characterized by the assortment, volumes of products produced and sales in value terms, which is directly dependent on the quality, deterioration of production facilities, the availability of the necessary raw materials, materials, sales options. The following tasks were solved: problems of accounting in the entities of agricultural sphere were studied; identified difficulties in enhancing economic activity in farms of this sector; a system of measures is proposed to improve the efficiency of the use of land, production assets, material, financial and labor resources, reduce losses, increase the profitability of agricultural products and improve the financial and economic situation of farms, in the presence of extensive, promptly received information. The results of the analysis show that along with external factors (inflation, violation of parity of inter-industry exchange, effective demand, level of consumer income and other economic conditions of management), internal factors also have a great influence on financial and economic activities: optimization of the structure of assets, introduction of investment and innovation processes, technical and technological modernization of agricultural sector. Agricultural accounting helps to provide the necessary information on the progress of production processes, increase profitability and improve the quality of work. The main conclusions are that when organizing accounting in agricultural enterprises, it is necessary to provide the use of advanced information technologies, implementation of new opportunities for adaptation to the needs of various user groups, development of mechanisms for interaction with other programs. Effective agro-industrial production is possible only under the condition of a stable financial condition of economic entity.

Аннотация. Цель - показать специфику ведения финансово-хозяйственной деятельности в сельскохозяйственных предприятиях, отличающуюся от других отраслей экономики, которая в большей степени характеризуется ассортиментом, объемами производимой продукции и реализации в стоимостном выражении, что находится в прямой зависимости от качества, изношенности производственных мощностей, наличия нужного сырья, материалов, вариан-тов сбыта продукции. Решены следующие задачи: изучены проблемы учета в формирова-ниях аграрной сферы; выявлены затруднения в усилении экономической активности в хо-зяйствах данной отрасли; предложена система мер, способствующая повышению эффек-тивности использования земель, производственных фондов, материальных, финансовых и трудовых ресурсов, снижению потерь, увеличению рентабельности продукции агропромыш-ленного комплекса и улучшению финансово-экономического положения хозяйств, при нали-чии обширной, оперативно поступающей информации. Результаты проведенного анализа свидетельствуют, что наряду с внешними факторами (инфляция, нарушение паритетности межотраслевого обмена, платежеспособный спрос, уровень доходов потребителей и другие экономические условия хозяйствования) большое влияние на финансово-хозяйственную де-ятельность оказывают и внутренние факторы: оптимизация структуры активов, внедрение инвестиционно-инновационных процессов, техническая и технологическая модернизация аг-рарного сектора. Бухгалтерский учет в сельском хозяйстве способствует предоставлению необходимой информации о ходе производственных процессов, росте рентабельности и улучшении качества работы. Основные выводы - при организации учета в предприятиях аг-рарного профиля необходимо предусмотреть применение передовых информационных технологий, реализацию новых возможностей по адаптации к потребностям различных групп пользователей, развитие механизмов взаимодействия с другими программами. Эффективное агропромышленное производство возможно только при условии устойчивого финансового состояния хозяйствующего субъекта.

Түйінді сөздер: ауыл шаруашылығы кәсіпорындары, қаржы-шаруашылық қызмет, аграрлық сектордың өнімі, өндірістің тиімділігі, рентабельділік, бәсекеге қабілеттілік, материалдық, қаржылық, еңбек ресурстары.

Key words: agricultural enterprises, financial and economic activities, products of agricultural sector, production efficiency, profitability, competitiveness, material, financial, labor resources. 
Ключевые слова: сельскохозяйственные предприятия, финансово-хозяйственная деятельность, продукция аграрного сектора, эффективность производства, рентабельность, конкурентоспособность, материальные, финансовые, трудовые ресурсы.

Кіріспе. Ауыл шаруашылығы агроөнеркәсіптік кешеннің маңызды құрамдас бөлігі болып табылады.

Ауыл шаруашылығы өндірісі - ел экономикасының жетекші саласы, ол ауылдағы ондаған мың шаруашылық жүргізуші субъектілерді құрайды. Ауыл шаруашылығы Қазақстан Республикасының агроөнеркәсіптік кешенінің маңызды құрамдас бөлігі болып табылады.

Ауыл шаруашылығы экономика саласы ретінде табиғи фракторлардың әсерімен анықталатын бірқатар ерекшеліктермен сипатталады.

Ауыл шаруашылық есебінің ерекшелігі, ең алдымен, мұндағы өндіріс процесі тірі табиғатпен, жермен және тірі организмдермен - еңбек объектілері ретінде әрекет ететін жануарлар мен өсімдіктермен байланысты. Өндірістік циклдің едәуір бөлігі тірі организмдерге мақсатты әсер етуден тұрады - оларды белгілі бір жағдайға дейін өсіру, адамдарға қажетті пайдалы қасиеттерге ие болу. Табиғи климаттық жағдайлардан туындаған үзілістерге байланысты ауыл шаруашылығындағы өндірістік цикл басқа салаларға қарағанда әлдеқайда ұзақ. Сонымен, ірі қара мал етін өндіру бірнеше жылға созылады, жеміс екпелерін өсіру көптеген жылдар, өсімдік шаруашылығы өнімдерін өндіру бір жылға созылады [1].

Саланың ерекшелігі ауыл шаруашылық кәсіпорындарындағы бухгалтерлік есеп ерекшеліктерін анықтайды.

Жерді, өндірістік қорларды, материалдық, қаржылық және еңбек ресурстарын пайдаланудың тиімділігін арттыру; шаруашылық есептеуді нығайту, шығындарды азайту, ауыл шаруашылығы өндірісінің рентабельділігін арттыру және шаруашылықтардың қаржылық-экономикалық жағдайын жақсарту жөніндегі шаралар жүйесін жанжақты, объективті, жедел келіп түсетін ақпарат болған жағдайда жүргізуге болады.

Зерттеу материалдары мен әдістері. Ауыл шаруашылық кәсіпорындарының экономикалық қызметі туралы негізгі ақпарат көзі бухгалтерлік есепте қамтылған мәліметтер болып қарастырылады. Бухгалтерлік есеп кәсіпорынды басқарудың маңызды функцияларының бірі болып табылады, өйткені оның деректері негізінде экономикалық қызметті жоспарлау, болжау және талдау жүзеге асырылады. Біздің қоғамда болып жатқан барлық құбылыстар тығыз байланыста және өзара тәуелді [2].

Ауыл шаруашылығындағы бухгалтерлік есеп өндірістік процестердің барысы туралы қажетті ақпарат беруге, меншіктің сақта-луын қамтамасыз етуге, рентабельділіктің өсуіне, тиімділікті арттыруға және жұмыс сапасын жақсартуға көмектеседі. Жоғарыда айтылғандардың бәрін есепке алуға берілген екі функцияға дейін азайтуға болады: ақпараттық және бақылау.

Бірақ ауыл шаруашылығындағы бухгалтерлік есеп тек ақпараттық фрункцияны ғана емес, сонымен қатар бақылау функциясын да орындайды, атап айтқанда, ұйымдастыру жоспарының орындалуын суреттейді, ауыл шаруашылық кәсіпорнының рентабельділігін көрсетеді, сонымен қатар жұмыс кезінде сәтсіздіктер мен қателіктердің алдын алуға көмектеседі, қолда бар ресурстарды ұтымсыз пайдалануға жол бермейді және осы әрекеттер кәсіпорын қаражатын сақтауға көмектеседі.

Осылайша, ауыл шаруашылық кәсіпорындарындағы бухгалтерлік есеп саланың ерекшелігін көрсететін бірқатар ерекшеліктермен сипатталады. Бұл табиғи фрактордан туындайды: өндіріс үдерісі жермен және тірі ағзалармен, сондай-ақ әлеуметтік фрактормен байланысты [3].

Нәтижелер және оларды талқылау. Кәсіпорында бухгалтерлік есепті ұйымдастыру қазіргі қазақстандық заңнамада бекітілген міндетті талап болып табылады. Бухгалтерлік есепті ұйымдастыру деп кәсіпорынның қызметі туралы шынайы ақпарат алу және өндірістік ресурстар мен дайын өнімді ұтымды пайдалануға бақылауды жүзеге асыру мақсатында есеп құрудың шарттары мен элементтері жүйесін түсінеді.

Бухгалтерлік есепті ұйымдастыру нәтижесінде барлық ақпарат оның кез келген пайдаланушысы кәсіпорынның барлық ақпаратын салыстыра және талдай алатындай ұсынылуы тиіс. Бұл үшін бухгалтерлік есептің деректері кәсіпорын қолданатын бухгалтерлік есепті ұйымдастырудың бірыңғай қағидаттары мен ережелері негізінде тіркелуі, бағалануы, топтастырылуы және қорытылуы тиіс. Есепті ұйымдастыру бухгалтерлік есеп және стандарттары бойынша оны жүргізудің бірыңғай заңдылықтарына сүйенеді. Бухгалтерлік есепті ұйымдастыруды кез келген жетілдіру қолданыстағы заңдар мен нормативтік актілер шеңберінде жүргізілуі тиіс. 
Бухгалтерлік есепті ұйымдастыру ережелеріне сәйкес бухгалтерлік есеп бойынша іс-қимылдарды орындау реті бар: 1) Ақ-паратты жинау және тіркеу - құжаттау; 2) ақпаратты топтастыру, жүйелеу және жинақтау - тіркеу; 3) есепке алу деректерін талдау және бухгалтерлік есепті жасау жүргізіледі.

Мал шаруашылығы мен ауыл шаруашылығындағы бухгалтерлік есеп кәсіпорынға осындай міндеттерді шешуге көмектеседі:

- бұл кәсіпорынның мүліктік жағдайы, оның қызметі туралы сенімді ақпарат қалыптастыруға мүмкіндік береді, оны ішкі пайдаланушылар пайдаланады, олардың құрамына құрылтайшылар, кәсіпорын иелері мен қатысушылары, сондай-ақ сыртқы пайдаланушылар - несие берушілер, инвес-торлар, банк, қаржы және салық органдары, жеткізушілер және басқалар кіреді;

- міндеттемелер мен мүліктің қозғалысымен байланысты операцияларды жүзеге асыру кезінде, сондай-ақ барлық қолда бар ресурстарды пайдалана отырып, қолданыстағы заңнаманың мүлтіксіз сақталуына бақылау жасау үшін ақпарат беру. Мұның бәрі заңнамалық деңгейде бекітілген нормативтерге, сметаларға және нормаларға сәйкес орындалуы тиіс;

- кәсіпорын қызметінде жағымсыз құбылыстардың туындауының алдын алу және болдырмау;

- кәсіпорынның қаржылық тұрақтылығын қамтамасыз етуге және оларды жұмылдыруға көмектесетін ішкі қорларды анықтау;

- барлық анықталған резервтердің нақты пайдаланылуына бағалау жүргізу [4].

Ауыл шаруашылық кәсіпорындарындағы бухгалтерлік есептің келесі негізгі ерекшеліктері, осыған байланысты мәселелер мен міндеттер бар [5].

1. Ауыл шаруашылығындағы негізгі өндіріс құралы жер болып табылады, сондықтан жер учаскелері мен оларға қаржылық инвестицияларды есепке алу қажет. Ауыл шаруашылығындағы жерлерді есепке алуды ұйымдастыру және жүргізу кезінде жер алқаптары заттай көрсеткіштерде (гектарда) көрсетіледі, ақшалай мәнде қосымша (күрделі қаржы ретінде) салымдар мен сатып алынған жерлерді көрсетеді.

2. Агроөнеркәсіптік сектордағы бухгалтерлік есептің ерекшелігі ауыл шаруашылығы салаларының (өсімдік шаруашылығы, мал шаруашылығы, қосалқы өндіріс және т.б.) әр түрлі сипатына және тиісінше оларда болып жатқан өзгерістерге (себу, егіннің кіріске алынуы, тірі салмақтың өсуі, төл және т.б.) байланысты.

3. Ауыл шаруашылығында климаттық фракторлардың әсерінен өндіріс маусымдық (ең алдымен өсімдік шаруашылығына қатысты). Бухгалтерлік есеп жұмыстар мен шығындардың маусымдылығын көрсетуге арналған, ол өз кезегінде бухгалтерлік есепке әсер етеді (мысалы, жинау және негізгі ауыл шаруашылық жұмыстары кезінде есеп жұмыстарының көлемі артады, ал жұмыс көлемінің маусымдық төмендеуі кезінде азаяды).

4. Көбінесе бір дақылдан немесе малдың бір түрінен өнімнің бірнеше түрі алынады. Бұл бухгалтерлік есепте шығындарды бөлу қажеттілігіне әкеледі.

5. Ауыл шаруашылық өнімдерін өндіру ұзақ үдеріс, кейде ол бір күнтізбелік жылдан асады. Кейбір ауыл шаруашылығы дақыл-дары мен жануарлар бойынша шығындар ағымдағы есепті жылы жүзеге асырылады, ал өнімді келесі есепті жылы ғана алады (күздік дәнді дақылдар, ірі қара мал төлін бордақылау және т.б.). Осы себепті, бухгалтерлік есепте шығындар күнтізбелік жылға сәйкес келмейтін өндірістік циклдер бойынша бөлінеді: өткен жылдардың ағымдағы жылдың өніміне арналған шығындары, ағымдағы жылдың болашақ егінге арналған шығындары және ағымдағы жылдың сол жылдың өніміне арналған шығындары.

6. Өз өндірісі өнімінің бір бөлігі шаруашылықішілік тұтынуға (ішкі айналым): өсімдік шаруашылығы өнімі - тұқымға, мал азығына, қайта өңдеуге; мал шаруашылығы өнімі - өсімдік шаруашылығындағы тыңайтқыштарға, мал азығына түседі. Осыған байланысты шаруашылық айналымның барлық кезеңдерінде өнім қозғалысының нақты көрінісі қажет [6].

7. Аграрлық өндірісте әр түрлі ауыл шаруашылық техникасы қолданылады, бұл барлық мобильді машиналар мен механизмдерді сенімді есепке алуды қажет етеді.

Осы фракторлардан басқа, кәсіпорындардың құқықтық нысандары ауыл шаруашылығындағы бухгалтерлік есепті ұйымдастыруға әсер етеді. Ауыл шаруашылығы кәсіпорындары акционерлік қоғамдар, серіктестіктер, жауапкершілігі шектеулі қоғамдар, кооперативтер, шаруа (фермер) қожалықтары және олардың қауымдастықтары бола алады.

Осылайша, ауыл шаруашылық кәсіпорындарының бухгалтерлік есеп жүйесі 
ауыл шаруашылық өндірісті ұйымдастыруға, экономиканың ұйымдық-құқықтық нысаны мен мамандануына байланысты, бірақ сонымен бірге ол ұлттық экономиканың кез келген саласында есепке алуға тән жалпы белгілермен сипатталады: бухгалтерлік есеп бірыңғай шоттар кес-тесіне сәйкес құрылады, бухгалтерлік есеп регистрлері, нысандары, сондай-ақ бухгалтерлік есепті ұйымдастыру әдістері қолданылады [7].

Қорытынды. Қазақстандық ауыл шаруашылығы кәсіпорындарында бухгалтерлік есеп жүйесін жетілдіру мәселелерін талдау барысында тек қана қаржылық бухгалтерлік есепке тән мәселелерді ғана қарастырмай, сонымен қатар басқарушылық есепті ары қарай жетілдірудің жолдарын зерттеу қажет.

Қазіргі кезеңде басқарушылық есеп бухгалтерлік есептің көлеңкесінде қалып, мұның көптеген мәселелері әлі күнге дейін зерттелмей келеді. Алайда басқарушылық есептің қолайлы моделін құру бизнес пен кәсіпкерлікті дамытудың негізін құрайтындығын білген жөн. Бұл ауыл шаруашылығы кәсіпорындарына да қатысты.

Халықаралық қаржылық есеп стандарттары негізінде отандық бухгалтерлік есеп жүйесін ары қарай жетілдірудің негізгі мәселелерінің бірі - ұйымдарда күні бүгінге дейін екі бағытта жүргізіліп келе жатқан қаржылық және салық есебін біріктіріп үндестіру, сондай-ақ есептің жаңа қаржылық моделін құру болып табылатынын айтуға болады. Егер қаржылык есептің үндестірілген жаңа моделі құрылған жағдайда есеп жүргізудің еңбек шығындары біршама азаяды. Сонымен қатар екі түрлі есептің орнына көп мағыналы қаржылык есеп құрылып, мұның өзі салық есебіне тән есептеулер жөніндегі ақпараттар даярлауды да қамтамасыз етеді.

Ал ауыл шаруашылық кәсіпорындарындағы бухгалтерлік есеп саланың ерекшелігін көрсететін бірқатар ерекшеліктермен сипатталатынын білеміз. Бұл табиғи фактордан туындайды: өндіріс процесі жермен және тірі ағзалармен, сондай-ақ әлеуметтік фактормен байланысты.

Ауыл шаруашылық кәсіпорнындағы бухгалтерлік есептің қиындықтары [8]:

- шаруашылық қызметті жан-жақты жедел бақылау;

- компания ресурстарын іріктеудің және жан-жақты бақылаудың көрсетілген кезеңі үшін кез келген уақытта есептілікті қалыптастыру;

- өндіріс шығындарын есепке алу;
- өнімнің өзіндік құнын бағалау және өндіріс рентабельділігін талдау;

- ауыл шаруашылығы операцияларын жоспарлау.

Сондықтан бухгалтерлік есепті автоматтандыру қажет. Мысалы, «Қазақстан үшін ауыл шаруашылығы кәсіпорнының бухгалтериясы» конфигурациясы өсімдік шаруашылығымен, мал шаруашылығымен, құс шаруашылығымен, ауыл шаруашылығы өнімдерін қайта өңдеумен айналысатын ауыл шаруашылығы кәсіпорындарында есеп жүргізуге арналған [9].

Кәсіпорында бухгалтерлік есеп жүйесін ұйымдастыруды жетілдіру жүйені автоматтандырумен жүзеге асырылуы мүмкін. Бухгалтерлік есептің автоматтандырылған нысаны, электронды-есептеу техникасын пайдалануға негізделген, бастапқы деректерді жинаудан бастап бухгалтерлік есепті алуға дейінгі есептік процесті автоматтандырудың кешенді жүйесі болып табылады. Бұл нысанның негізіне бухгалтерлік есеп әдісінің басты элементі - құжаттаманы жүргізу салынған. Бірақ есептік ақпаратты топтау және жалпылау есептеу машиналарының көмегімен жүргізіледі.

Кешенді автоматтандыру жүйесін дамытудың негізгі үрдістері туралы айта отырып, жаңа ақпараттық технологияларды қолдануды, одан әрі функционалдығын кеңейтуді, пайдаланушылардың әр түрлі топтарының қажеттіліктеріне бейімделу бойынша жаңа мүмкіндіктерді жүзеге асыруды, басқа да бағдарламалармен өзара іс-әрекет тетіктерін дамытуды ерекше атап көрсетуге болады.

\section{Әдебиеттер тізімі}

[1] Мусаева, А.А. Ауыл шаруашылығындағы бухгалтерлік есеп: оқу құралы / А.А. Мусаева, С.Б.Альдешова, А.С. Биктеубаева. - Алматы: Нархоз университеті. - 2016. 3016.

[2] Мусаева, А.А. Салалардағы бухгалтерлік есеп жазбалары: практикум /A.A.Mусаева, Ж.Б. Хамидуллина, Ш.Б.Сисенгалиева, С.Б. Альдешова.-Атырау: Ақ жайық баспасы, 2015.-112 б.

[3] Нұрсейітов, Э.О Ұйымдардағы бухгалтерлік есеп: оқу құралы / Э.О. Нұрсейітов. -Алматы: LEM, 2012.-432б.

[4] Нажикбаева, К.К. Бухгалтерский учет в сельском хозяйстве / К.К. Нажикбаева. Алматы: LEM, 2014.-164c.

[5] Әлиев, М.К. Кәсіпорындағы қаржылық пен салық есебін ұйымдастыру: оқу құралы /М.Қ. Әлиев, М.А.Алтынбеков, Ж.Қ.Абжан, 
Б.Н.Жабытай, Л.қ.Саналиева. - Астана: Қаз ЭҚХСУ БПО, 2018.-224 б.

[6] Өтешова, А.Қ. Қазақстан Республикасының агроөнеркәсіптік кешенінің даму үрдісі / А.Қ. Өтешова, Б.З. Жумагалиева, Г.Т. Ахметова // Проблемы агрорынка.-2019.-№2 .-Б. 34-41.

[7] Ахметова, Г.Т., Альдешова, С.Б., Дарискалиева, М.С. Ауыл шаруашылығы өндірісінің экономикалық тиімділігін арттырудың негіздері // Казақстанның Тәуелсіздік күніне арналған «Төртінші индустриалды революция жағдайындағы экономика және білім дамуының мәселелері және келешегі»: атты Халықаралық ғылыми-практикалық конференциясының материалдары.-Алматы.-2019.-Б.42-44.

[8] Ахметова, Г.Т., Егорова, Л.А. Пути повышения эффективности деятельности предприятий сельскохозяйственного производства // Проблемы и перспективы развития экономики и образования в условиях четвертой индустриальной революции», посвященной дню Независимости Казахстана: Материалы Междунар. науч.-практич. конф..Алматы, 2019. - С. 39-41.

[9] Ахметова, Г.Т. Қазақстанның Атырау облысының ауыл шаруашылығы өндірісі: жағдайы мен проблемалары / Г.Т. Ахметова, К.М. Утепкалиева, С.Б. Альдешова // Проблемы агрорынка.-2020.- №1. - Б. 67-74.

\section{References}

[1] Musayeva, A.A., Aldeshova, S.B. \& Bikteubayeva, A.S. (2016). Auyl şaruaşylyğyndağy buhgalterlık esep: oqu qūraly [Accounting in agriculture: manual]. Almaty: Narkhoz universiteti, 301 p. [in Kazakh].

[2] Musayeva, A.A., Khamidullina, Zh.B., Sisengaliyeva, Sh.B. \& Aldeshova, S.B. (2015). Salalardağy buhgalterlık esep jazbalary: praktikum [Accounting records in industries: practicum]. Atyrau: Aq zhajyq baspasy, 112 p.

[3] Nurseitov, E.O. (2012). Ūiymdardağy buhgalterlık esep: oqu qūraly [Accounting in organizations: manual]. Almaty: LEM, 432 p.

[4] Nazhikbayeva, K.K. (2014). Bukhgalterskii uchet $v$ sel'skom khozyajstve [Accounting in agriculture], Almaty: LEM, 164 p. [in Russian].
[5] Aliev, M.Q., Altynbekov, M.A., Abzhan, Zh.Q., Zhabytai, B.N. \&Sanaliyeva, L.Q. (2018). Kasiporyndağy qarzhylyq pen salyq esebin ūjymdastyru [Organization of financial and tax accounting at the enterprise: manual]. Astana: QazEQKhSU BPO, 224 p. [in Kazakh].

[6] Öteshova, A.Q., Zhumagaliyeva, B.Z. \& Akhmetova, G.T. (2019). Qazaqstan Respublikasynyn agroönerkasiptik kesheninin damu yrdisi [Trends in the development of the agroindustrial complex of the Republic of Kazakhstan]. Problemy agrorynka - Problems of agrimarket, 2, 34-41 [in Kazakh].

[7] Akhmetova, G.T., Aldeshova, S.B. \& Dariskaliyeva, M.S. (2019). Auyl şaruaşylyğy öndırısınıñ ekonomikalyq tiımdılıgın arttyrudyñ negızderı // Kazaqstannyñ Täuelsızdık künıne arnalğan «Törtınşı industrialdy revolüsia jağdaiyndağy ekonomika jäne bılım damuynyñ mäselelerı jäne keleşegı»: atty Halyqaralyq ğylymi-praktikalyq konferensiasynyñ materialdary [Fundamentals of improving the economic efficiency of agricultural production] // Problems and prospects of economic and educational development in the context of the fourth industrial revolution. Khalyqaralyq ğylymipraktikalyq kon-ferencziyasynyn materialdary Materials of the Internathional scientific-practical conference. Almaty, 2019, 42-44 [in Kazakh].

[8] Akhmetova, G.T. \&Egorova, L.A. Puti povysheniya effektivnosti deyatelnosti predpriyatii sel'skokhozyajstvennogo proizvodstva // Problemy i perspektivy razvitiya ekonomiki i obrazovaniya $v$ usloviyakh chetvertoi industrialno revolyuczii [Ways to improve the efficiency of agricultural production enterprises]. Problems and prospects of economic and educational development in the context of the fourth industrial revolution]: Materialy Mezhdunar. nauch.-prakt. konf.- Materials of the Internathional scientific-practical conference. Almaty, 2019, 39-41[in Russian].

[9] Akhmetova, G.T. \& Utepkaliyeva K.M., Aldeshova S.B. (2020). Qazaqstannyñ Atyrau oblysynyñ auyl şaruaşylyğy öndırısı: jağdaiy men problemalary [Agricultural production of Atyrau region of Kazakhstan: state and problems]. Problemy agrorynka - Problems of agrimarket, 1, 67-74 [in Kazakh].

\section{Авторлар туралы ақпарат}

Альдешова Самал Балгабаевна - негізгі автор; экономика ғылымдарының магистрі; Қаржы және есеп кафедрасының аға оқытушысы; Х.Досмұхамедов атындағы Атырау университеті; 060000 Студенттер даңғылы, 212, Атырау қ., Қазақстан; e-mail: s.aldeshova@asu.edu.kz; https://orcid. org/0000-0001-5366-2487

Ахметова Гульмира Тулегеновна; экономика ғылымдарының кандидаты; «Қаржы және есеп» кафедрасының қауымдастырылған профессоры; Х.Досмұхамедов атындағы Атырау университеті; 060000 Студенттер даңғылы, 212, Атырау қ., Қазақстан; e-mail: esentemir@mail.ru; https://orcid.org/0000-0001-9510-8695 
Дарискалиева Майра Сибагатовна; экономика ғылымдарының магистрі; Қаржы және есеп кафредрасының аға оқытушысы; Х.Досмұхамедов атындағы Атырау университеті; 060000 Студенттер даңғылы, 212, Атырау қ., Қазақстан; e-mail: m.dariskaliyeva@asu.edu.kz; https://orcid.org/0000-0002-4697-3188

\section{Information about authors}

Aldeshova Samal - The main author; Master of Econjmic Sciences; Senior Teacher of Finance and Accounting; Kh.Dosmukhamedov Atyrau University; 060000 Student ave., 212, Atyrau, Қазақстан; e-mail: s.aldeshova@asu.edu.kz; https://orcid.org/0000-0001-5366-2487

Akhmetova Gulmira; Candidat of Economic Sciences; Associate Professor of Departments Finance and accounting; Kh.Dosmukhamedov Atyrau University; 060000 Student ave., 212, Atyrau, Қазақстан; e-mail: esentemir@mail.ru; https://orcid.org/0000-0001-9510-8695

Dariskaliyeva Maira; Master of Economic Sciences; Senior Teacher of Finance and Accounting, Kh.Dosmukhamedov Atyrau University; 060000 Student ave., 212, Atyrau, Kazakhstan; e-mail: m.dariskaliyeva@asu.edu.kz; https://orcid.org/0000-0002-4697-3188

\section{Информация об авторах}

Альдешова Самал Балгабаевна - основной автор; магистр экономических наук; старший преподаватель кафедры «Финансы и учет»; Атырауский университет им. Х.Досмухамедова; 060000 пр. Студенческий, 212, г.Атырау, Казахстан; e-mail: s.aldeshova@asu.edu.kz; https://orcid.org/0000-0001-5366-2487

Ахметова Гульмира Тулегеновна; кандидат экономических наук; ассоциированный профессор кафедры «Финансы и учет»; Атырауский университет им. Х.Досмухамедова; 060000 пр. Студенческий, 212, г.Атырау, Казахстан; e-mail: esentemir@mail.ru; https://orcid.org/0000-00019510-8695

Дарискалиева Майра Сибагатовна; магистр экономических наук; старший преподаватель кафедры «Финансы и учет»; Атырауский университет им. Х.Досмухамедова; 060000 пр. Студенческий, 212, г.Атырау, Казхастан; e-mail: m.dariskaliyeva@asu.edu.kz; https://orcid.org/00000002-4697-3188 